\title{
Erratum to: Refining landscape contexts for open-air, Lower and Middle Paleolithic sites: a case study from Muthanna Province, Southern Iraq
}

\author{
Joseph Schuldenrein
}

Published online: 15 February 2015

(C) Springer-Verlag Berlin Heidelberg 2015

\section{Erratum to: Archaeol Anthropol Sci}

DOI 10.1007/s12520-014-0215-2

The original article, unfortunately, contained an error.

The image captured for Figure 8 is incorrect. The correct figure is shown in the following.



Fig. 8 Cumulative percentages for very fine sand and silt fractions in Geo-trench 1 with clays removed. General distribution presented in $1 / 2$ phi increments

The online version of the original article can be found at http://dx.doi.org/ $10.1007 / \mathrm{s} 12520-014-0215-2$.

\section{J. Schuldenrein $(\bowtie)$}

Geoarchaeology Research Associates, 92 Main Street, Suite 207,

Yonkers, NY 10701, USA

e-mail: joseph.schuldenrein@gra-geoarch.com

URL: http://www.gra-geoarch.com 